\title{
Impact of Tourism Destination Based on The Stakeholder's Perception: A Cases Study in Jakarta Old Town, Indonesiai
}

\author{
Himawan Brahmantyo ${ }^{1}$, Muhammad Baiquni ${ }^{2}$, Chafid Fandeli ${ }^{3}$, Tri Widodo ${ }^{4}$ \\ ${ }^{I}$ Tourism Study Program, Graduate School Program, Gadjah Mada University, Jl. Teknika Utara, Pogung \\ Yogyakarta and Trisakti Institute of Tourism, Jl. IKPN, Tanah Kusir, South Jakarta \\ ${ }^{2}$ Gadjah Mada University, Regional Development Dept., Faculty of Geography, Jl. Sekip Utara, Bulaksumur, \\ Yogyakarta. \\ ${ }^{3}$ Gadjah Mada University, Forest Resource Conservation Dept., Faculty of Forestry, Jl. Agro, no.1, \\ Bulaksumur, Yogyakarta. \\ ${ }^{4}$ Gadjah Mada University, Economics Dept., Faculty of Economics and Business, Jl. Sosio Humaniora, \\ Bulaksumur, Yogyakarta.
}

\begin{abstract}
Stakeholders has significant role in tourism destination development. The aims of the research is to determine the stakeholders perceptions related to the impact of tourism development in Jakarta Old Town. Field survey was conducted through questionnaire distribution to local community, businessmen and governmental officers in Jakarta Old Town area as one of the main tourism destination in Jakarta, Indonesia. Result of the survey shows that stakeholders argues that tourism in Jakarta Old Town contributes significant impact to understanding of other culture (mean $=4,33)$, improvement of facilities (mean $=4,29)$, increase of economic benefits among small enterprises $(m=4,27)$, increasing pride(mean $=4,26)$, creating Jobs $(m=4,23)$ and renovation of historical old building (mean $=4,19$ ). Therefore, tourism development in Jakarta Old City area contributes positive impact to the local and regional development. There are however, improvement in some area of services and management. It is especially important to increase the sustainability of tourism in Jakarta Old Town area.
\end{abstract}

Keywords -Heritage tourism, destination management, tourism stakeholders

\section{Introduction}

National historical heritages are the important aspect for national tourism development. It is particularly important in Jakarta Old Town, Indonesia. This area has been recognized with its national history and endowed by numerous historical building and story. In Indonesia, it is especially important to increase numerous resources related to natural and cultural heritage as tourism attraction [1] [2] [3] [4].

In the colonial era, this area was known as Batavia, the important city of the Vereenigde Oostindische Compagnie (VOC), a Dutch company in South East Asia in the past century. In the past, Batavia very famous and called as "Diamond of Asia" and "Queen of Asia". Christopher Fryke visited Batavia in 1680-an, and argues that Batavia more beautiful than Amsterdam. Innigo de Biervillas, has visited Batavia in 1718, and report his deep impression to the city of Batavia and its environments [4] [5]. The Jakarta Old Town or Batavia has numerous old and historical building. The architectural of building was the combination of the BaroqueRococo as an architecture style of middle era to the Art-Deco as an architectural style of $20^{\text {th }}$ century. Some old building recently becomes museum, including City Hall (established at 1707) as National Historical Museum (Museum Fatahillah), The Justice Office becomes Art and Ceramics Museum, and old church as WayangMuseum [5].

In many modern countries, historical building was viewed as national assets for the development of tourism destinations [1]. In such a case, the revitalization of Batavia has been viewed important. During 20062014, the renovations of buildings and infrastructure were done. Several improvements have been done in Jakarta Old Town. It is including management of local seller and parking system in Fatahillah Park. There is also management of rivers to increase environmental health and clean. These programs has been identified contributes to increase Jakarta Old Town performance [4][5][6].

The Jakarta Old Town area has proposed by the Jakarta provincial government of as one of the World Heritage Site of UNESCO in 2017. Through the status, it is expected Jakarta Old Town widely recognized and number of tourist to the old town increase. Tourism grows in Jakarta Old Town has been addressed to trigger and support the local economic development and national earning from tourism industry [4].

The role of stakeholder in tourism destination and attraction development has been reported important [3][7][8]. In the development of tourism attraction, the perception of stakeholder was important. In case of Jakarta Old Town, few data available regarding the stakeholder perception to the tourism impact, especially in the economical, social and environmental issues. The aim of the research was to identify the stakeholder 
perceptions to the economical, social and environmental impact of tourism destination development in Jakarta Old Town. This information was significant to evaluate and construct the sustainable and competitive tourism destination.

\section{Study area}

\section{Methods}

Jakarta Old Town administratively is part of the Jakarta city, the capital city of Indonesia. The province of Jakarta consist of lands about $661.52 \mathrm{~km}^{2}$ and marine about $6,977.5 \mathrm{~km}^{2}$. According to demographic census in 2011, number of citizens was about 10,187,595 [9]. Jakarta is the centre of national business, politics and culture. Administratively, Jakarta Province divided into five administrative area, West Jakarta, Central Jakarta, East Jakarta, South Jakarta, North Jakarta and one District, namely Kepulauan Seribu (Thousand Islands).

The Jakarta Old Town administratively belongs to West and North Jakarta. In the past, this area can be said as the capital city of Dutch East Indies in era of colonialism. In the past, this area is the central area for business and politics. Recently, many place and object has been visited as historical tourism attractions, namely Sunda Kelapa Port, Bahari Museum, Fish market and shipyard/fort in Penjaringan sub Regency (North Jakarta). Many historical building belongs of the West Jakarta, including Jakarta Historical Museum, Fatahillah Park, Wayang Museum, Art and Ceramics Museum, Intan Bridge, and Red Shop. These located at Tamansari and Tambora sub regency, West Jakarta [4][5][6].

According to Jakarta Old Town Management Plan 2014, the vision and mission of the old town was creating the area of old town (an area about 334 hectare) as a cultural heritage that has high economic value through tourism, business and trading activity. The concept of development was regulated in Governor law No. 36 / 2014. The development of area within wall (or fort in Batavia era) was addressed as an area with historical aspect with are main function encompasses education, cultural and social events, icons for tourism, replicates of old town of village (Kampung Bandan), Marine Museum, Fish market and shipyard/fort (Fig.1) [10].

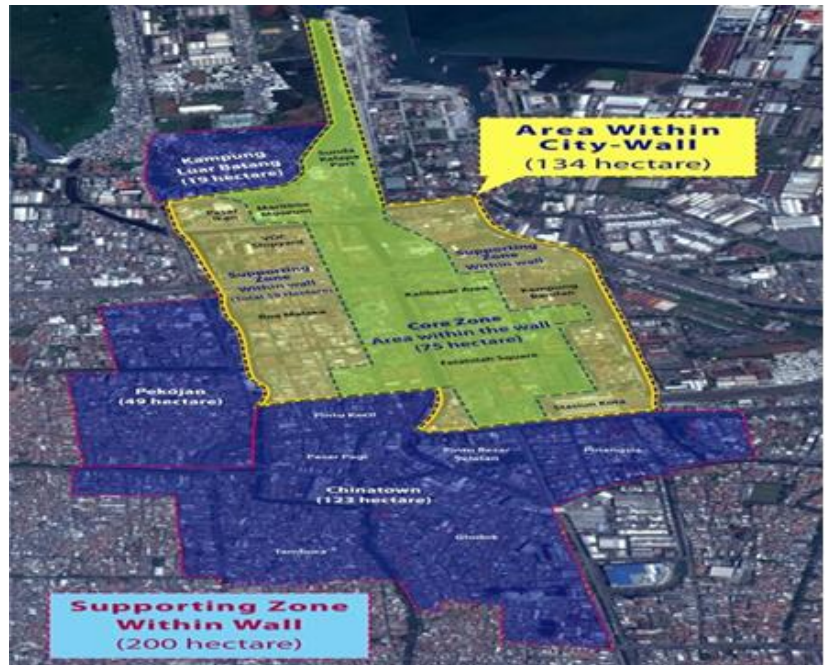

Fig. 1 Management plant of Jakarta Old Town (Source: Jeforah.org 2015)

In order to control and integrates coordination of all activity in Jakarta Old Town area, since 2007 the Governor Decree no. 127 year 2007 about Management Unit of Jakarta Old Town was released. This management unit was operated under Office of Tourism and Culture of Jakarta Province. The main task of the unit was making coordination among all of the related institution and stakeholders of Jakarta Old Town development.

Revitalization of Jakarta Old Town has been started at 2006, with some area such as Fatahillah Park, West and East Kali Besar, and Sunda Kelapa Port as a focus of revitalization programs. The limitation of the Jakarta Old Town was related to the buildings ownership. Among 284 units of recorded old building, only 6 buildings under the authority of Jakarta Province. Twenty three building belong to the Ministry of State Owned Enterprises (Badan Usaha Milik Negara, BUMN), while 255 buildings were belong to private company and individuals[4][5][6].

There are numerous stakeholders identified related to the Jakarta Old Town development. Stakeholder mapping conducted by UNESCO identifies 3 Ministry, 8 institutions and office under Jakarta provincial government, 4 institutions under west and north Jakarta city administration, 4 groups of privates sectors, and 61 communities has direct access and ownership to the building in Jakarta Old Town. These groups have different 
interest and types of uses of buildings. These aspects lead to the lack of coordination as the problem for the development [4][10][11].

\section{Methods Respondent Samplings}

Field survey was done in Jakarta Old Town from February to June, 2015 through questionnaire distribution to local community, tourism businessman and government officer of Jakarta Province. The respondent of local community was selected from Pinangsia, Roa Malaka and Penjaringan. These villages located close to the Jakarta Old Town tourism object and many of the local community have interaction with visitors. The number of community in Pinangsia (West Jakarta) was about 13,224 individuals. Number of community in Roa Malaka (West Jakarta) was about 5,360 individuals. Number of local community in Penjaringan (North Jakarta) was about 15,289 individuals. The formula to estimate the sample number was based on Slovin formula:

$$
\mathrm{n}=\frac{N}{1+N e^{2}}
$$

in which : $\mathrm{n}=$ sample number

$\mathrm{N}=$ number of population

$\mathrm{e}=$ critical value

$\mathrm{n}=275,5$ or equal to 276 individuals

Totally there are 300 questionnaires were distributed proportionally with the composition of respondents 39\% (117 respondents from Pinangsia Village), 15\% (45 respondents from Roa Malaka Village), and 15\% (45 respondents from Penjaringan Village). Totally, 261 respondents completed the survey, with a response rate of approximately $87 \%$.

The selected tourism businessmen includes people those has direct business activity and service to tourist in Jakarta Old Town. These includes staff of hotels, restaurant, café, member of old bicycle rentals (Onthel Wisata community), Manusia Batu community and small trader called Pedagang Kaki Lima. Non probability sampling with accidental techniques was used to select sample of the study. About 175 questionnaires were distributes to the respondents in Fatahillah Park, Roa Malaka and Marine Museum. From all distributed questionnaires, about 133 respondents filled out completely the questionnaires for further analysis. The response rate of questionnaires was approximately $76 \%$.

The respondents of local governmental officers consist of staff from Management Unit of Jakarta Old Town (9 respondent), Jakarta Historical Museum ( 7 respondents), Art and Ceramics Museum (7 respondents), and Marine Museum (14 respondents). All of questionnaires which was distributed to the respondents returned completely (100\%), and the questionnaires can be used for further analysis.

\section{Questionnaire Design and Evaluation}

The questionnaires consist of two main parts. The first part consist of questions related to the respondent profiles, and the second part was the question related to the impact of economical, social and environmental aspect of tourism development. In each question, questions answer was given following Likert scale. It was ranging from 1 for very disagree, 2 for disagree, 3 for neutral, 4 for agree and 5 for very agree. There are nine indicators to evaluate economic, social and environmental aspect of Jakarta Old Town tourism development. From all respondents, about 261 local community fill out the questionnaires, followed by businessmen (133 respondents) and government officers of Jakarta city (48 respondents).

The validity of questionnaires was tested using Pearson correlation test. Each question related to the impact of economical, environmental and social aspects were tested using total variable score by Product Moment correlation test. The value of correlation test was compared with critical value. The reliability test was done to observe numbers of questions as reliable variable to describes the impact of economical, social and environmental aspect of tourism development. The question can be said reliable if Cronbach's Alpha has value more than 0.6.Result of the validity and reliability test was given in Table 1.

Table 1. The validity and reliability test

\begin{tabular}{|c|c|c|c|c|}
\hline Variable & Question items & Correlation value & Cronbach's Alpha & Notes \\
\hline \multirow[t]{3}{*}{ Economical impact } & Creating jobs & 0.374 & 0.665 & \multirow{4}{*}{$\begin{array}{l}\text { The validity } \\
\text { and reliability } \\
\text { question item } \\
\text { were moderate }\end{array}$} \\
\hline & Benefits for small business & 0.489 & 0.665 & \\
\hline & Increase of goods prices and service cost & 0.222 & 0.665 & \\
\hline Environmental & Facility improvement & 0.311 & 0.665 & \\
\hline
\end{tabular}


Impact of Tourism Destination Based on The Stakeholder's Perception: A Cases Study in Jakarta.....

\begin{tabular}{|l|l|l|l|}
\hline \multirow{3}{*}{ impact } & Historical Building renovations & 0.388 & 0.665 \\
\cline { 2 - 4 } & Air pollution & 0.291 & 0.665 \\
\hline \multirow{3}{*}{ Social impact } & Understanding another culture & 0.415 & 0.665 \\
\cline { 2 - 4 } & Provide prides & 0.486 & 0.665 \\
\cline { 2 - 4 } & Increase of criminality & 0.287 & 0,665 \\
\hline
\end{tabular}

Data Analysis: Data was analyzed using SPSS Statistical package version 20.0. The different perception between stakeholders was analyzed using ANOVA and t-test.

\section{Respondent profiles}

\section{Result And Discussion}

The distribution of respondent in the survey was given in Table 2 .

Table 2. Profile of respondents

\begin{tabular}{|c|c|c|c|c|c|c|}
\hline Parameters & $\begin{array}{l}\text { Local community } \\
(\mathrm{n}=261)\end{array}$ & $\%$ & $\begin{array}{l}\text { Businessmen } \\
(\mathrm{n}=133)\end{array}$ & $\%$ & $\begin{array}{l}\text { Government officials } \\
(\mathrm{n}=48)\end{array}$ & $\%$ \\
\hline \multicolumn{7}{|l|}{ Ages } \\
\hline $19-34$ & 87 & 33.33 & 48 & 36.09 & 19 & 39.58 \\
\hline $35-50$ & 126 & 48.28 & 69 & 51.88 & 20 & 41.67 \\
\hline $51-67$ & 48 & 18.39 & 16 & 12.03 & 9 & 18.75 \\
\hline \multicolumn{7}{|l|}{ Sex } \\
\hline Male & 164 & 62.84 & 92 & 69.17 & 31 & 64.58 \\
\hline Female & 97 & 37.16 & 41 & 30.83 & 17 & 35.42 \\
\hline \multicolumn{7}{|c|}{ Education background } \\
\hline Elementary school & 14 & 5.36 & 8 & 6.02 & 1 & 2.08 \\
\hline Junior high school & 79 & 30.27 & 24 & 18.05 & 0 & 0 \\
\hline Senior high school & 116 & 44.40 & 77 & 57.89 & 33 & 68.75 \\
\hline Diplomas & 15 & 5.75 & 9 & 6.77 & 5 & 10.42 \\
\hline Graduates & 34 & 13.03 & 15 & 11.27 & 8 & 16.67 \\
\hline Post graduate & 3 & 1.15 & 0 & 0 & 1 & 2.08 \\
\hline
\end{tabular}

Based on the respondents characteristics, there are no significant different among stakeholders. The majority of respondents based on the respondent's age was 35-50 years old. Mostly it was dominated by male. In the perspective of education background, most of the respondent finished high school education level. These characteristics shows that basically respondent has knowledge, awareness and critical thinking on the impact of economic, social and environments of tourism destination development in Jakarta Old Town.

\section{Local community perception the impacts of tourism development. \\ Economical impacts}

The majority of respondents argues that tourism in Jakarta Old Town contributes to economical aspect through new creation and availability of jobs $(90.80 \%)$. Few respondents disagree with this impact $(1.54 \%)$. Therefore it can be concluded that tourism has economic benefits for local people, and the development of infrastructure, facility and attraction is important to generate more visitor to visit Jakarta Old Town. The development of Fatahillah Park as an open green space area combining with the existence of museums (i.e. Jakarta Historical Museum, Wayang Museum and Art and Ceramic Museum) attract tourists to come the area and able to provides market for economic activities. There are snacks, drinks, and souvenirs traders. Restaurant and other tourist services also grows in this area to provides numerous visitor grows. The services operated by local people area encompass photography, bicycle rentals (sepeda onthel) and guide. These open new opportunities for local economic activities and development. In many case, spatial planning and arrangement is the important aspect to increase economic benefits of destination area. It is especially important in Jakarta Old Town [12].

Most respondents argues that tourism in Jakarta Old Town provides opportunities for small enterprises to grows (93.11\%). Tourism stimulates number of traders in Fatahillah Park. There are at least 415 traders found in Jakarta Old Town area. According to the Jakarta tourism officers, in some moment such as festivals, number of traders can reach 1.000 individuals. Festivals are one of the important aspects to increase tourist number in particular area [13]. In festivals there are numerous economic opportunities, in which it is provides benefits for local people [14].

Different responses occurs in the perception of the increase of goods prices and service cost as an impact of tourism development. Based on the calculation, 39.85\% respondents shows disagree and very disagree perceptions that tourism contributes to the high price of goods and service in the area. About $14.56 \%$ respondents argues that tourism contributes to the increase of prices in tourism destination area. There are $45.59 \%$ respondents has moderates perception. It means that respondents argue that the price in Jakarta Old 
Town is normal and similar with prices in other area such as in Mangga Dua or Glodok. Price is crucial aspect in tourism destination competitiveness. Therefore, destinations managers should be aware on such issues[15]

\section{Environmental Impacts}

Respondent agree that the development of tourism destination lead to the development of public facilities in an area surrounding Jakarta Old Town $(88.61 \%)$. About $0.76 \%$ respondent was disagree. Before the area management was implemented, the Jakarta Old Town was considered as free area for common public transportation, trucks, motor bikes and private cars. After management implemented, these area was prohibited as transportation corridors. The transportation management allow Fatahillah Park free from public transportation and became safe place for visitors. There are improvement of park, park lamp and electricity to increase visitor satisfactions. The development of tourism was able to protect historical building. In order to attract more tourists, architectural and historical sites are restored and protected [16] This is relevant with the study finding, in which 91.19\% respondents argue that tourism able to protect historical buildings in Jakarta Old Town. These performances cannot be separated from Jakarta provincial policy and programs to increase the function of museum, including Wayang Museum, Jakarta Historical Museum, Art and Ceramics Museum and Marine Museum. There are also management of Kali Besar become the health river.

About $36.78 \%$ of local community disagree that tourist contributes to the traffic congestion and other transportation problems, including air pollution. About $21.07 \%$ agree that tourism contributes to the traffic jam and pollutions. About $42.15 \%$ respondents argues that there are no correlation between tourism activities and transportation problems. It is related to the fact that in the past, the area of Jakarta Old Town has been recognized as an area with dense population of vehicles. Scholars point out that tourism contributes to the environmental impact, including traffic congestions. The community perceived impact of tourism has been identified numerous. The perspective of local community on the impact of tourism development was important, especially to generates local community support in destination development[17][18][19].

\section{Social impacts}

About $96.17 \%$ of respondents agree that tourism contributes to the social aspect especially in the introduction of other culture. A lot of visitor number on destination provides opportunities for local people to interact and learn about visitor's culture. There are also interactions among visitors and these relations open new opportunities to open visitor's experiences. About $97.32 \%$ of respondents agree that tourists' activities visiting Jakarta Old Town able to increase local community awareness on their cultural heritage history and create pride of nationality. Few respondent (2.68\%) point out that tourism programs in Jakarta Old Town contributes on cultural heritage history and increase nationality. Related to the impact of tourism development in criminality, about $49.05 \%$ of respondents disagree that tourism contributes to criminality. About $10.34 \%$ argues that tourism contributes to criminality, and $40.61 \%$ argues that there are no relationship between tourism development and criminality.

Social impact of tourism development has been widely identified by scholars. Concern about social impact of tourism has been evolved as an effort to create sustainable tourism comprehensively. Criminality is the concern of social impact of tourism. Understanding social impact therefore important in tourism development [20]. These informations especially important to increase community participation in tourism development [17] [21].

\section{Tourism businessmen perception on the impacts of tourism development. The economical impact.}

The development of Fatahillah Park as an open space and centre of people activity lead to the increasing number of visitors. This situation lead to the numerous business opportunities, including numerous goods and services related to the visitor needs. These lead to the perception that tourism has ability to open new jobs and generates new economic activity. About $97.74 \%$ of the respondents agree with such situations. According to survey data, $98.49 \%$ respondents agree that tourism contributes to the benefits of small enterprises. Based on the field observation, the traders in Fatahillah Park was dominated by small and medium businessmen and trader, in which their activity depend on the visitor in Jakarta Old Town. The development of Jakarta Old Town in 2012 has significant impact on the increase of visitor number. In the same situation, there are also environmental problems and visitors satisfactions.

In order to increases the capacity of local tourism businessmen participation in economic activity in Jakarta Old City, the local government has increase the human capacity of 415 local traders in Fatahillah Park to provide better service and professionalism in tourism destinations. There are different perceptions among respondents related to the goods and service price. About $54.89 \%$ disagree that tourism contributes to the increase of goods and service price, while $9.02 \%$ agree that tourism contributes to the increase of goods and 
service price in Jakarta Old Town. High prices of goods and service lead has been identified related to tourism destinations, as they might go up with the increased demand from foreign customers[15].

\section{The social Impact.}

The majority of respondents argue that tourism lead local tourism businessmen understand other cultures $(97.74 \%)$. Tourism also contributes their national pride $(94.74 \%)$.According to respondents and tourists, the historical buildings and cultural heritage in Jakarta Old Town tell numerous aspects related to the national history. These lead to the increase of pride of nationality. There also argument for the important of national heritage preservation among respondents and tourism.

There are disagree perception that tourism contributes to increase the criminality $(54.88 \%)$, while $6.77 \%$ respondents argues that tourism lead to the criminality incidents. Based on the field observation, businessmen fell the location was safe and few criminalities occur. The security system in the Jakarta Old Town area has been viewed able to protect visitors and trader from inconvenient situation, including criminality. Safety is the main consideration for trading, including in tourism area. In many countries, government pay a lot of attention to the tourism safety issues as one of the important aspect in destination competitiveness [22].

\section{Environmental Impacts.}

About $97.75 \%$ respondents agree that tourism development contributes to the public facility development. Tourism development also contributes to the renovation programs of buildings in Jakarta Old Town area. About $97 \%$ of respondents agree that old building can be converted as tourism attraction, including museum. The renovation of old building influence tourist satisfaction. The improvement of park, including park lamps create safe environment for tourist, especially in the night. There are $47.37 \%$ respondents disagree that tourism contribute to traffic congestion. About $7.52 \%$ argues that tourism influence traffic congestions. There are $45.11 \%$ respondents with neutral perception, means that before and after development of tourism there are no significant different. Overcrowding and congestion are often significant issues [23]. In Jakarta Old Town area, these issues perceived as common phenomena. According to respondents, for a long time the area of Jakarta Old Town has been identified as a busy area with its traffic congestion. Most respondents argue that tourism only contribute partially to traffic congestion.

\section{Local Governmental officer perception on the impacts of tourism development. Economic impact}

According to local Governmental officers' perception, tourism contributes significantly in providing jobs for local community $(83.33 \%)$. Increase of visitor number create opportunities for numerous business and create the local people creativity to produce numerous goods and services related to tourism. Some creativity can be seen in the case of "manusia patung". In this case, the needs of visitor to take photo with the background of national figure with specific costumes, clown, and ghost, lead to the creatively of local people to create new products. The similar case was found in old bicycle (sepeda ontel). The bicycle rentals grow significantly as a new business opportunity. Using bicycle, visitor can explore all of the Jakarta Old Town area.

About $93.75 \%$ of respondents agree that tourism provides economic benefits for local community. In the field, this can be observed that increase of visitation lead to the increase of new small businesses, including restaurants, souvenirs trader, and other services. There are different perspectives related to goods and service price. About $45.84 \%$ respondents disagree and $29,17 \%$ very disagree that tourism contributes the high prices. About $27.08 \%$ were able to accept that the high of prices were caused by tourism industry. These means, tourism viewed as an important instrument for local economic growth. These aspect lead governments pay a lot of attention in tourism development. This phenomena similar with other regions in numerous countries [24].

\section{Environmental impact}

Respondents argues that tourism contributes to the development of infrastructure and public facility. About $39.58 \%$ respondents agree and $56.25 \%$ very agree with the statements. According to respondents, there are significant changes of the Jakarta Old Town environment, including the development and increasing facility for tourist. In the past, the east area of Kali Besar was dirty area, but recently it is clear and beautiful. The situation in Fatahillah Park recently very clean and attractive with numerous tourist attraction. Many tourist attractions was initiated and organized by local people. About $81.25 \%$ of respondents agree that tourism development contributes to the renovation of historical sites. According to respondents, the Province of Jakarta has made numerous regulation and action related to the renovation of Jakarta Old Town. As far, the renovation of Jakarta Historical Museum, Marine Museum and area management of East Kali Besar has been done. There are $56.25 \%$ of respondents has perception disagree to very disagree on the issues of tourism contributes to the traffic congestions. About $18.75 \%$ agree and $14.58 \%$ very agree that tourism contributes to the transportation system problems, including traffic congestion. According to respondents, traffic congestion is the classical 
problems of the big city. In Jakarta, it has been recognized occurs in everywhere, especially in an area with abundance visitor and tourism activities. These is similar with other cases in the world, where tourism development often lead to the traffic congestion [23]. Absent of the proper urban planning especially contributes to the traffic problems, including in tourism area [25].

\section{Social impact}

About $91.67 \%$ of local government officers agree that tourism contributes to social aspect, especially in increasing understanding about tourists' cultures. Based on the calculation $6.25 \%$ was neutral and $2.08 \%$ disagree with this statement. Tourism contributes to the awareness of the historical and cultural heritages and increase pride of nationality, about $89.59 \%$ respondents agree with this statement, only $8.33 \%$ respondents shows doubtful perception, and $2.08 \%$ disagree with the statement. In the perspective of tourism impact on criminality, respondents disagree that tourism contribute to criminality $(47.92 \%)$. Different from other stakeholders, $49.99 \%$ respondents has perception that tourism contributes to criminality and few respondents doubtfully on the impact of tourism in criminality (2.09\%). These situation especially similar with other tourism destination, especially in developing countries [22].

\section{Different perception among stakeholders}

The comprehensive analysis on perception about impact of tourism development in Jakarta Old Town as tourism destination was given in Table 3 .

Table 3. Indices of tourism destination impacts

\begin{tabular}{|l|l|l|l|l|l|l|l|}
\hline No & Variables & Indicator & $\begin{array}{l}\text { Local } \\
\text { Community }\end{array}$ & Businessmen & $\begin{array}{l}\text { Govt. } \\
\text { officers }\end{array}$ & Total & Averages \\
\hline 1 & Economy & Creating jobs & 4.13 & 4.23 & 4.33 & 12.69 & 4.23 \\
\hline & & Benefits for small business & 4.17 & 4.24 & 4.41 & 12.82 & 4.27 \\
\hline & & $\begin{array}{l}\text { Increase of goods prices and } \\
\text { service cost }\end{array}$ & 2.71 & 2.53 & 2.68 & 7.92 & 2.64 \\
\hline 2 & Environ-ment & Facility improvement & 4.10 & 4.27 & 4.52 & 12.89 & 4.29 \\
\hline & & Historical Building renovations & 4.16 & 4.16 & 4.27 & 12.59 & 4.19 \\
\hline & & Air pollution & 2.83 & 2.60 & 2.70 & 8.13 & 2.71 \\
\hline 3 & Social & Understanding another culture & 4.31 & 4.20 & 4.50 & 13.01 & 4.33 \\
\hline & & Provide prides & 4.22 & 4.10 & 4.47 & 12.79 & 4.26 \\
\hline & & Increase of criminality & 2.57 & 2.48 & 2.93 & 7.98 & 2.66 \\
\hline
\end{tabular}

Based on the Table 3, all of the stakeholders argues that tourism in Jakarta Old Town contributes significant impact to understanding of other cultures (mean $=4.33)$, improvement of facilities $($ mean $=4.29)$, increase of economic benefits among small enterprises $(\mathrm{m}=4.27)$, increasing pride (mean $=4.26)$, creating jobs $(\mathrm{m}=4.23)$ and renovation of historical old building (mean $=4.19)$. This is relevant with previous findings that tourism contributes positive impact to development [1] [3] [8].

\section{Different perception among stakeholders}

The different of stakeholders perception was given in Table 4.

Table 4. Stakeholders perspectives related to impact of tourism development to social-economical and environmental aspects.

\begin{tabular}{|c|c|c|c|}
\hline \multicolumn{4}{|c|}{ Overall impact } \\
\hline \multicolumn{2}{|c|}{ Variables } & Mean difference & P- Value \\
\hline Local community & Businessmen & 0.725 & 0.038 \\
\hline Local community & Govt. Officers & -1.295 & 0.012 \\
\hline Businessmen & Govt. Officers & -2.02 & 0.000 \\
\hline
\end{tabular}

There different perception between local community and businessmen ( $\mathrm{p}$-value $0.038<$ alpha $=0.05$ ) According to local people, the most aspect related to tourism impact is social aspect. It was followed by economical attributes. Economical attributes includes provides benefits for small enterprises and provides new jobs. Conversely, among businessmen, tourism development was important for facility improvement, provides benefits for small enterprises, and creates new jobs. These perceptions cannot be separated from stakeholder's interest. Local community seems to be aware on social impact [16] [17].

Local community and local governmental officers has different perception about the impact of tourism destination development ( $\mathrm{p}$-value $=0,012<$ alpha $=0,05)$. Social aspect is the most important among local community. Social aspect related to introduction of culture and provides prides, while the economical aspect was received less attentions. Governmental officers have high interest to environmental aspects with infrastructure and facilities development is the main interest. It was followed by social aspects as the second 
priority. These data shows that there are similar perceptions among stakeholders in the perspectives of social aspects. Respondents argue that there is negative and positive impact of tourism. The local provincial government has paid attention to such issues due to these aspect related to the governmental responsibility [8] [26].

The perception between businessmen and local governmental officers was significant ( $\mathrm{p}$-value $=0.000$ $<$ alpha $=0.05$ ). In the perspectives of businessmen, aspect related to business was the main factor to determines the interest of impact. The facility improvement will lead to the satisfaction of visitors and therefore increase the economical benefits of businessmen. Increase of visitor lead to the opportunities for jobs and other economic activities. According to local government officers, the environmental aspect is important. The improvement of local environment can be implemented through improvement of public facilities. Tourism also plays an important role in facilitating the exchange of cultures and creating opportunities to learn other people. Seeing their own community become popular and well-known tourist destination can improve the awareness and pride of local community [1].

Overall, this research confirm that tourism stakeholders in Jakarta Old Town has its perceptions which are important for destination development. The management of destination based on the tourism stakeholders' perception was important. It is especially important to accomodate numerous issues and interest to achieve sustainable tourism development in Jakarta Old Town [27].

\section{Conclusion}

Stakeholder's perception to the tourism destination and object was important. Local government should put a lot of attention to the development of tourism destination attraction. It is especially important to increase tourists' satisfaction. The positive perception to the tourism development lead to the positive support for destination sustainability. The information related to the stakeholder's perception is important for planning and development, especially in deciding development priority. In the limitation of budget and other resources for development, the proper decision to implement strategic development was important.

The development of tourism in Jakarta Old Town is relatively slow. The heterogenity of stakeholders and its' interest seems contributes to the destination development. There are however, increase of community creativities which are important in local economic development. These contribute to the positive impact to the community, especially in the community prosperity. Therefore, it is needed the comprehensive policy which are able to integrated numerous stakeholder's perspectives into comprehensive planning and management.

\section{References}

[1] Y. Poria, R. Butler and D. Airey, The core of heritage tourism, Annals of tourism research, 30(1), 2003, 238-254.

[2] L. Hakim, SK. Hong, JE. Kim and N. Nakagoshi,). Nature-based Tourism in Small Islands Adjacent to Jakarta City, Indonesia: A case study from Seribu Islands. Journal of Korean Wetland Society. 9(1), 2007, 31-46.

[3] J. Damanik, Pariwisata Indonesia, antara peluang dan tantangan (Pustaka Pelajar, Yogyakarta, 2013).

[4] A. Robertson, E. Sutanudjaja, A. Henderson and MI. Kusalasari, Analytical Study of Kota Tua Jakarta (UNESCO, Jakarta 2014).

[5] A. Heuken, Historical Sites of Jakarta (Cipta Loka Caraka, Jakarta,2000).

[6] L. Suratminto, and M. Karim, Historia Jakarta;Kota Tua punya cerita (PT Kompas Media Nusantara, Jakarta,2012).

[7] K. Andriotis, Community Groups' Perceptions of and Preferences to Tourism Development. Evidence from Crete, Journal of Hospitality and Tourism Research, 29 (1), 2005, 67-90.

[8] F. Aref, SS. Gill, and IF. Aref, Tourism Development in local Communities; As a Community Development Approach, Journal of American Science 6(2), 2010, 155 - 161

[9] Badan Pusat Statistik Provinsi DKI, Jakarta dalam angka 2014 (BPS, Jakarta, 2014).

[10] [10] TDKD. Jakarta, Rencana Induk Kota Tua Jakarta-. A Vibrant, Diverse, and Living Cultural Heritage District (DKI Jakarta, 2007).

[11] Peraturan Gubernur Provinsi DKI Jakarta nomor 36 Tahun 2014 tentang Rencana Induk Kawasan Kota Tua (Jakarta, 2014)

[12] R. Aryanto and IG. So, Perencanaan manajemen lanskap zonasi destinasi wisata budaya Kota Tua Jakarta. Binus Business Review, 3(2), 2012, 973-982.

[13] JL. Crompton, and SL. McKay, Measuring the economic impact of festivals and events: Some myths, misapplications and ethical dilemmas. Festival Management and Event Tourism, 2(1), 1994, 33-43.

[14] D. O'Sullivan and MJ. Jackson, Festival tourism: a contributor to sustainable local economic development? Journal of Sustainable Tourism, 10(4), 2002, 325-342.

[15] L. Dwyer, P. Forsyth and P. Rao, The price competitiveness of travel and tourism: a comparison of 19 destinations. Tourism Management, 21(1), 2000, 9-22.

[16] J. Liu, and T. Var, Resident attitudes toward tourism impacts in Hawaii. Annals of Tourism Research. 13, $1986,193-214$.

[17] KL. Andereck, KM. Valentine, RC. Knopf and CA. Vogt, Residents' perceptions of community tourism impacts. Annals of tourism research, 32(4), 2005, 1056-1076.

[18] A. Pizam, Tourism impacts: the social costs to the destination community as perceived by its residents. Journal of Travel Research. $16(4), 1978,8-12$

[19] R. Purdue, TP. Long, and L. Allen, Resident support for Tourism development. Annals of Tourism Research. 17 (4), 1990, 586599.

[20] BS. Duffield, Tourism: the measurement of economic and social impact. Tourism Management, 3(4), 1982, $248-255$.

[21] JD. Timothy, Participatory planning : a view of tourism in Indonesia. Annals of Tourism Research. 26, 1999, 371 - 391.

[22] Y. Mansfeld, and A. Pizam, Tourism, security and safety (Routledge, 2006) 
[23] E. Fredline and B. Faulkner, Resident reactions to a major tourist event: The Gold Coast Indy car race. Festival Management and Event Tourism, 5(4), 1998, 185-205.

[24] CO. Oh, The contribution of tourism development to economic growth in the Korean economy. Tourism management, 26(1), 2005, 39-44.

[25] EL. Glaeser and ME. Kahn, Sprawl and urban growth. Handbook of regional and urban economics, 4, $2004,2481-2527$.

[26] DE. Hawkins and S. Mann, S. The World Bank's role in tourism development. Annals of Tourism Research, 34(2), 2007, $348-363$.

[27] A. Presenza and M. Cipollina, Analysing tourism stakeholders networks. Tourism Review, 65(4), 2010, 17-30. 